\title{
Jana Szymczyka rozumienie aksjologicznego wymiaru polskiej socjologii
}

$\int_{\text {matykę teoretyczną, jak i empiryczną. Zajmował się ogólną tematyką socjolo- }}^{\text {an Szymczyk podejmował w swoich badaniach naukowych zarówno proble- }}$ giczną - koncepcjami socjologii - oraz szczegółowymi tematami wchodzącymi w zakres socjologii szczegółowych - wartości, media, państwo, naród, władza, ruchy społeczne, sztuka, sport, turystyka, ciało. Był jednak w dużej mierze systematykiem i historykiem polskiej myśli socjologicznej w jej poszczególnych odniesieniach tematycznych. W niniejszym artykule podejmę kwestię jego rozumienia polskiej socjologii jako osadzonej w uniwersalnych wartościach humanistycznych. Stawiam tezę, że we wszystkich tekstach J. Szymczyka polska socjologia postrzegana jest jako powiązana z określonym systemem wartości, co wyznacza sposób identyfikowania w niej realnych problemów i poszukiwania najlepszych ich rozwiązań. Odnoszenie się do socjologii polskiej ma w jego pismach charakter świadomego zabiegu pogłębiania tradycji myślenia socjologicznego i osadzania jej w historycznych warunkach życia określonej wspólnoty nieco w opozycji do koncepcji ciągłego nadążania za tzw. socjologią światową i kosmopolitycznym otwarciem kulturowym. Wykażę, że lubelski socjolog nie czynił jednak tego w przekonaniu, że o porządku społecznym powinno się mówić w ramach socjologii narodowych, ale uznawał, iż uniwersalny język naukowy wymaga osadzenia w systemie wartości właściwych dla danej wspólnoty narodowej.

* Dr hab. Arkadiusz Jabłoński, prof. KUL - Katedra Teorii Społecznych i Socjologii Rodziny, Instytut Nauk Socjologicznych, Wydział Nauk Społecznych, Katolicki Uniwersytet Lubelski Jana Pawła II, e-mail: arkadiusz.jablonski@kul.pl, ORCID: 0000-0001-8081-2217. 


\section{Filozofia a socjologia}

W ujęciu J. Szymczyka rzeczywistość badana przez socjologię jest w dużym stopniu amorficzna i znajdująca się procesie ciągłego stawania się. Wielokrotnie zatem powtarzał w swoich pismach, że rozumienie zjawisk społecznych wymaga osadzenia w ramach uniwersalnych i niezmiennych kategorii. Do wyznaczenia tych ram nadają się głównie principia filozoficzne. Jak jednak się nimi posługiwać, aby nie podważyć autonomii socjologii jako nauki? Które z tych principiów - logiczne, metodologiczne, metafizyczne, ontologiczne, antropologiczne, etyczne, aksjologiczne - wybrać za ramy określające ogląd i opisy rzeczywistości społecznej?

Związki między filozofią a socjologią pojmowane są na różne sposoby. Skrajnymi podejściami są całkowite podporządkowanie socjologii założeniom filozofii, uznanie socjologii za nowoczesną formę myślenia filozoficznego oraz przyjęcie zupełnej odrębności obu dyscyplin. Możliwe są także stanowiska pośrednie, które szanując autonomię dyscyplinarną socjologii, wskazują na jej zależności od założeń filozoficznych. Uznanie ich jako warunku koniecznego uprawiania socjologii może dotyczyć wielu poziomów tej zależności ${ }^{1}$. Podkreślać można powiązania socjologii z principiami logicznymi, metodologicznymi, epistemologicznymi, ontologicznymi, etycznymi i politycznymi.

Filozofów i socjologów niemal od zawsze interesowało to, jak rozwija się człowiek i kształtuje swoją osobowość w warunkach wyznaczanych przez społeczeństwo. Wiązało się to $\mathrm{z}$ interpretacją poczucia sprawstwa (agency) ${ }^{2}$ człowieka w sytuacji, gdy oddziałują na jednostkę różne społeczne zjawiska i struktury. Problematyka ta w refleksji naukowej stała się przedmiotem oglądów i konstruowania na ich podstawie obrazów życia społecznego. Filozoficzna eksplikacja źródeł życia społecznego, natury interakcji, elementów strukturalnych rzeczywistości społecznej i form życia zbiorowego pozwalała wnosić twórczy wkład do ogólnego dorobku socjologii i jej subdyscyplin.

${ }^{1}$ „W podejściu uzależniającym logikę nauk społecznych od zasad nauki, problematyka socjologiczna traktowana jest jako wtórna wobec pierwotnych rozstrzygnięć natury metanaukowej i metodologicznej. Dyskusja ta naznaczona jest piętnem konfrontacji między teoretycznymi (metodologicznymi i potocznymi) wyobrażeniami na temat nauk przyrodniczych, a praktyką nauk społecznych. $Z$ jednej strony prowadzi to do programu budowy nauk społecznych na wzór wyobrażeń o naukach przyrodniczych, z drugiej strony owocuje koncepcjami odmienności lub osobliwości nauk społecznych, w porównaniu z tymi wyobrażeniami na temat nauk przyrodniczych". A. Jabłoński, Budowanie społeczeństwa wiedzy. Zarys teorii społecznej Karla. R. Poppera, Wydawnictwo KUL, Lublin 2006, s. 229. Zob. też. A. Jabłoński, Filozoficzna interpretacja życia społecznego w ujęciu Petera Wincha, Redakcja Wydawnictw KUL, Lublin 1998.

${ }^{2}$ Sprawstwo. Teorie, metody, badania empiryczne w naukach społecznych, red. A. Mrozowicki, O. Nowaczyk, I. Szlachcicowa, Zakład Wydawniczy „Nomos”, Kraków 2013. 
Zainteresowania naukowe J. Szymczyka kształtowała długoletnia przynależność instytucjonalna do Katedry Filozofii Społecznej ${ }^{3}$ oraz własne zainteresowania problematyką filozoficzno-antropologiczną i społeczną, uprawianą w ramach chrześcijańskiej myśli społecznej. Wywiódł stąd przekonanie, że ustalenia filozoficzne stanowią podstawę każdej refleksji humanistyczno-społecznej. Socjologia oznaczała dla niego zajmowanie się przedmiotem, który jest dziełem ludzi, efektem czyichś działań wcześniejszych, a zarazem tworzyw dla konstrukcji przyszłej. „Uchwycenie "całej» drogi pomiędzy horyzontem oczekiwań (marzeniami, projektami) a faktami czy pomiędzy wartościami immanentnymi - odczuwanymi - uznawanymi (realizowanymi) nie jest łatwe, a tak naprawdę niemożliwe do adekwatnego zaprezentowania. Ale wejście na ten szlak poznawczy i kroczenie nim, na tyle, na ile się da, znacznie poszerza naszą perspektywę oglądu ludzkich zachowań, postaw, motywacji, uwarunkowań. (...) Socjolog nie może wziąć w nawias tego, co łączy się ze sferą podmiotowości, świadomości, aktywizmu, ludzkiej twórczości. (...) Owo poszerzanie, czyli pogłębianie, badań oznacza w wielu przypadkach skorzystanie przez socjologa z zaplecza innych nauk, przynajmniej z pewnych wypracowanych w ciągu minionych stuleci ich kategorii pojęciowych"4.

Takim pojęciem była dla J. Szymczyka osoba ludzka i wywodzące się z personalizmu traktowanie człowieka jako zdolnego do większej afirmacji swojego „być" nad „mieć". Ujawniło się to w sposób znaczący w trakcie jego analiz zasady dobra wspólnego, rozumienia wartości społecznych czy ciała ludzkiego, w których zawsze podkreślał znaczenie pozamaterialnych sfer życia. Personalizm pozwalał mu na połączenie dynamizmu socjologicznego oglądu świata z traktowaniem człowieka jako bycia, konstytuującego się także w wymiarze społecznym i przez życie społeczne. Unikał tym samym redukcjonizmu socjologicznego czyniącego człowieka bytem ukształtowanym przez społeczeństwo, ale nie popadał także w przesąd indywidualistycznego humanizmu czyniącego człowieka miarą wszystkiego ${ }^{5}$.

${ }^{3}$ Bezpośrednim mistrzem oraz promotorem jego pracy magisterskiej i dysertacji doktorskiej był ks. prof. Stanisław Kowalczyk. Od niego nauczył się personalistycznego podejścia, które lubelski filozof zawarł w szeregu znaczących pism odnoszących się do problematyki człowieka (Człowiek w myśli współczesnej. Filozofia współczesna o człowieku, Wydawnictwo „Michalineum”, Warszawa 1990), społeczeństwa (Człowiek a społeczność. Zarys filozofii społecznej, Redakcja Wydawnictw KUL, Lublin 1996), kultury (Filozofia kultury. Próba personalistycznego ujęcia problematyki, Redakcja Wydawnictw KUL, Lublin 1996), wartości (Współczesny kryzys ideowo-aksjologiczny, Wydawnictwo KUL, Lublin 2011; Filozofia wolności. Rys historyczny, Redakcja Wydawnictw KUL, Lublin 1999; Wolność natura i prawem człowieka. Indywidualny i społeczny wymiar wolności, Wydawnictwo Diecezjalne, Sandomierz 2000; Idea sprawiedliwości społecznej a myśl chrześcijańska, Redakcja Wydawnictw KUL, Lublin 1998), ciała (Ciało człowieka $w$ refleksji filozoficznej, Wydawnictwo KUL, Lublin 2009), sportu (Elementy filozofii i teologii sportu, TN KUL, Lublin 2002).

${ }^{4}$ J. Szymczyk, Pomiędzy marzeniami a faktami. Szkice socjologiczne, Norbertinum, Lublin 2005, s. 151-152.

${ }^{5}$ Tenże, Odkrywanie wartości. Z problematyki socjologiczno-aksjologicznej, Polihymnia, Lublin 2004, s. 11-97. 
W napisanej wspólnie książce ${ }^{6}$ (ostatniej publikacji, która wyszła za życia ks. Jana) przedstawiliśmy dziedzictwo mistrzów, którzy uczyli nas takiego myślenia. Wskazaliśmy w niej nie tylko na bogactwo odniesień do personalistycznego rozumienia człowieka i społeczeństwa, ale wręcz na próbę budowania personalistycznego wymiaru socjologii uprawianej w KUL. Rozpoczęło się to w latach dwudziestych ubiegłego stulecia od rozpoznania bezbożnego, antyhumanistycznego i totalitarnego wymiaru bolszewizmu. Podjęto z nim otwartą walkę na argumenty, zarówno w okresie niepodległości międzywojennej, jak i w powojennym ładzie po zajęciu ziem polskich przez sowietów. Nie zmieniał się cel, ale zmieniała się taktyka. Jeżeli jeden z omawianych autorów, Franciszek Mirek, czynił to, wprost sprzeciwiając się władzy bolszewików (za co w czasach PRL zapłacił więzieniem i pozbawieniem możliwości pracy naukowej), to Jan Turowski, Karol Wojtyła, Stanisław Kowalczyk, Franciszek Mazurek, Leon Dyczewski, Janusz Mariański, Jerzy Rebeta odnosili się do marksizmu-leninizmu, przeciwstawiając jego upraszczająco błędnym i amoralnym koncepcjom prawdziwe i słuszne moralnie podejścia do kwestii antropologiczno-społecznej. Dominowało wśród nich nastawienie czerpiące z myśli klasycznej (zwłaszcza Arystotelesowskiej) i scholastycznej (św. Augustyn i św. Tomasz z Akwinu) w dialogu ze współczesnymi koncepcjami (głównie z kantyzmem, fenomenologią i egzystencjalizmem), które krystalizowały się do postaci personalizmu chrześcijańskiego. Traktowanie człowieka jako osoby pozwoliło pogodzić substancjalną tożsamość i autonomiczność każdego człowieka w jego wymiarze ontologicznym ze społeczną naturą człowieka rozumianą relacyjnie.

J. Szymczyk w swoich pismach socjologicznych rzadziej posługiwał się pojęciem „osoby”, starając się używać bardziej socjologicznej terminologii - „podmiot”, „aktor”, „jednostka”, czy po prostu „człowiek”- ale w swoich analizach wyraźnie uwzględniał zarówno ludzki byt w sobie, odrębną ontologicznie substancjalną jedność, jak i byt dla siebie, świadomość siebie powiązaną relacjami z innymi w kształtowaniu „ja” podmiotowego i przedmiotowego. Identyfikując uniwersalne zasady ludzkiej świadomości, czyli to, co umożliwia ludziom definiowanie się jako część społeczeństwa, J. Szymczyk prowadził analizy dotyczące specyficznych współcześnie form doświadczania społeczeństwa ${ }^{7}$. Uniwersalne i naukowe oglądy życia społecznego powiązane są u niego z oglądem polskiej rzeczywistości społecznej. Opisując zachodzące w niej procesy i zjawiska, konstruuje na tej podstawie obrazy uwzględniające wyobrażenia historycznie ukształtowane w ramach ojczystego dziedzictwa strukturalno-kulturowego.

${ }^{6}$ A. Jabłoński, J. Szymczyk, Realist-axiological Perspectives and Images of Social Life. A Century of Sociology at John Paul the Second Catholic University of Lublin, Peter Lang, Berlin 2020.

7 J. Szymczyk, Elements of the Application of the Complementarity Principle. Issues of the Socjology of Subiectivity and Social Structures, Wydawnictwo Adam Marszałek, Toruń 2014, s. 11-118. 
Pozwoliło to lubelskiemu socjologowi odkrywać sfery rzeczywistości ludzkiej najbardziej narażone na unieważnienie w dyskursie teoretyczno-ideowym oraz na wykluczenie w płaszczyźnie praktyczno-społecznej. Przy okazji różnych analiz ujawnia on sposoby eliminowania kwestii Boga, religii, duszy, moralności, miłości, własności prywatnej, wspólnoty, cnoty, eschatologii, obiektywności (ontologicznej, epistemologicznej, aksjologicznej) itp. ze sfery rozważań naukowo-socjologicznych. W dominującej w socjologii tradycji pozytywistyczno-utylitarystycznej sfera ta została pozbawiona sensu lub potraktowana jako niebezpieczna ideologicznie. Dlatego J. Szymczyk poszukiwał pogłębionych refleksji filozoficznych, pozwalających na socjologiczną konceptualizację i operacjonalizację sfery aksjologiczno-duchowej życia społecznego. Wskazuje na socjologicznie uchwytną realność tych wymiarów rzeczywistości, a także uzgadnia je z różnymi teoriami, doktrynami i ideologami, ukazując miejsca wspólne i różnice niedające się zniwelować. Dlatego ze względu na status ontologiczny przedmiot nauk przyrodniczych odróżnia od przedmiotu nauk społecznych (socjologii), gdyż „w jednym przypadku mamy do czynienia $\mathrm{z}$ obiektami fizykalnymi, a w drugim z rzeczywistością znaczeń”. Dla J. Szymczyka istotne jest uznanie tych światów za równie realne i obiektywne ${ }^{8}$. Idzie tutaj drogą wyznaczoną przez Floriana Znanieckiego, wskazując na intersubiektywność jako specyfikę istnienia znaczeń, których doświadczanie „może być bez końca powtarzane przez nieograniczoną liczbę ludzi i tym samym weryfikowalne".

$\mathrm{Na}$ terenie nauk społecznych $\mathrm{w}$ różny sposób prezentowana jest relacja między strukturą społeczną a wartościami. Uzależnione to jest od przyjętej koncepcji struktury społecznej, jak i teorii wartości. Rozmaicie też opisywane są działania jednostek w społecznościach. Z jednej strony, interpretowane są jako bezwzględnie podległe determinacji strukturalnej (przynależności klasowo-stratyfikacyjnej, zawodowej itp.), narzucającej osobom określone wartości, normy, interesy, a z drugiej - eksponowane są ujęcia podkreślające wpływ wartości na preferencje i czynności ludzi tworzących i przekształcających struktury społeczne. Związek systemów wartości ze strukturą społeczną stanowi dla J. Szymczyka zasadniczy problem socjologicznych rozważań nad wartościami, a dotyczy to zarówno teorii, jak i badań empirycznych ${ }^{10}$.

W jego ujęciu „perspektywa aksjologiczna jest jednym z najbardziej istotnych podejść badawczych, dotyczących oglądów i obrazów konkretnych podmiotów i fenomenów życia społecznego. Aplikowanie jej w badaniach pozwala skonstatować, że socjologiczne obserwacje - prowadzone z punktu widzenia wartości

${ }^{8}$ Chodzi o realność, którą K.R. Popper przypisywał do świata 3, czyli m.in. odziaływanie na rzeczywistość fizyczną za pośrednictwem ludzkiego umysłu (świadomości). Zob. A. Jabłoński, Budowanie społeczeństwa wiedzy..., s. 111-119.

9 J. Szymczyk, Pomiędzy marzeniami a faktami..., s. 153.

10 Tenże, Elements of the Application of the Complementarity Principle..., s. 119-156. 
(ich deklarowania, a zwłaszcza uznawania i internalizowania) - dostarczają wielu cennych informacji na temat jakości różnych form i struktur życia publicznego, np. funkcjonowania ruchów społecznych"11. W innym miejscu dodaje, że „perspektywa aksjologiczna” czyni pisma ją uwzględniające stale żyjącymi, obchodzącymi ludzi, ważnymi współcześnie, nawet gdy powstały kilkadziesiąt czy kilkaset lat temu. Natomiast brak tej perspektywy pozbawia zapisane tysiące stron „większego waloru epistemologicznego"12. Z socjologicznego punktu widzenia konstatuje zatem, że ludzie kreują realia świata społecznego i różne konteksty kulturowe. Specyfikę czynności i działań społecznych podmiotów determinują określone zasady aksjonormatywne, wzory religijne i obyczajowe. Istnieje bowiem powszechne przekonanie - akceptowane także przez J. Szymczyka - że nie sposób do końca zrozumieć żadnej dziedziny ludzkiego życia, jeśli nie uwzględni się wartości i związanych z nimi norm czy także interesów. Wartości i interesy są szczególnie obecne w refleksyjnym doświadczeniu podmiotów życia społecznego. Stanowią niewyczerpane źródło motywacji i regulacji ludzkich zachowań i działań oraz pomagają wyjaśniać sens naszych postaw i interakcji.

\section{Socjologia polska czy uniwersalna}

W 2010 r. na łamach „Contemporary Sociology” rozgorzała dyskusja nad statusem socjologii i jej uniwersalnym charakterem jako nauki. Po przeciwnych stronach barykady stali dwaj Przewodniczący Międzynarodowego Towarzystwa Socjologicznego (ISA): w latach 2002-2006 Piotr Sztompka oraz w latach 2010-2014 Michael Burawoy. Punktem wyjścia dyskusji była poczyniona przez polskiego socjologa recenzja opracowania, którego współredaktorem był M. Burawoy, a zawierającego materiały z konferencji zorganizowanej w $2009 \mathrm{r}$. przez Tajwańskie Towarzystwo Socjologiczne i uczelnię Academia Sinica ${ }^{13}$. P. Sztompka ${ }^{14}$ ocenił to opracowanie jako znaczące marnowanie sił intelektualnych na czcze dywagacje podważające dorobek socjologiczny wielu krajów (np. Niemiec czy Włoch), a zwłaszcza Ameryki Północnej. Uznał to za przejaw

11 Tenże, Zamiast wprowadzenia. O Katedrze Socjologii Makrostruktur i Ruchów Społecznych, w: Wartości, interesy, struktury społeczne. Uwarunkowania ludzkiej kreatywności i partycypacji w życiu publicznym, Studia nad Wartościami. Perspektywa Socjologii Makrostruktur i Ruchów Społecznych, t. 1, red. J. Szymczyk, Norbertinum, Lublin 2010, s. 6-7.

12 Tenże, Odkrywanie wartości..., s. 8.

13 Facing an Unequal World: Challenges for a Global Soiology, red. M. Burawoy, M. Chang, M. Fei-yu Hsieh, Institute of Sociology at Academia Sinica, Council of National Associations of International Sociological Association, Academia Sinica, Taipei 2010.

14 P. Sztompka, Kolejna socjologiczna utopia, tłum. P. Walczyna, „Studia Litteraria et Historica” 2014/2015, nr 3/4, s. 335-349. 
dążenia środowiska Międzynarodowego Towarzystwa Socjologicznego do nadania „socjologii charakteru prawdziwie globalnej dyscypliny, co zapewniłoby równoprawny udział ośrodków naukowych z różnych krajów, a tym samym równorzędność odmiennych perspektyw i wyrugowanie uprzedzeń, o które posądzani są socjolodzy amerykańscy i europejscy"15.

Podejście to miało zahamować dominację euroamerykańskiego punktu widzenia w socjologii, który pod płaszczykiem obiektywności naukowej narzucany jest całemu światu. Zdaniem P. Sztompki stało się to sposobem na uprawianie ideologicznej refleksji nad socjologią europejską i amerykańską, gdzie opis i argumentacje zastąpione zostały przez sformułowania wartościujące i normatywne ${ }^{16}$. Sformułowaniami tymi zacierają różnicę między instytucjonalnym (tutaj możemy mówić o imperialnej przewadze Zachodu), a poznawczym wymiarem nauk, gdzie o wszystkim decydują sprawności intelektualno-metodologiczne dochodzenia do prawdy. Według tego badacza każdy - bez względu na narodowość i miejsce zamieszkania - może wnieść coś do światowej socjologii, gdy skupi się na realnych problemach dotyczących także społeczności narodowych i lokalnych, zamiast promować manifesty ideologiczne o potrzebie „alternatywnej socjologii” czy „lokalnej socjologii”. Dlatego P. Sztompka stoi na stanowisku uniwersalizmu naukowego, gdzie zgodnie $\mathrm{z}$ wymogami metodologicznymi określa się socjologiczny sposób odnoszenia się do badanych zjawisk w ramach określonych założeń teoretycznych.

Amerykański socjolog ${ }^{17}$ odpowiadając na tę recenzję, postanowił m.in. udowodnić, że uniwersalistyczne poglądy P. Sztompki w zakresie socjologii związane są z krajem jego pochodzenia, czyli z Polską. Jego zdaniem polski socjolog podważa rolę wspólnoty narodowej i nie zauważa, że pomimo dominacji sowieckiej socjologia w Polsce zdołała zachować odrębne tradycje, co świadczy, że są one w stanie przetrwać okres zewnętrznej dominacji. „Paradoksalnie, wstręt wobec idei socjologii lokalnych uniemożliwia Sztompce dojrzenie ich potencjału w zakresie kształtowania socjologii uniwersalnej. Socjologia uniwersalna nie może zostać odgórnie ustanowiona, wymaga bowiem żmudnych, starannych i długotrwałych badań na poziomie lokalnym ${ }^{18}$. M. Burawoy upatruje w socjo-

15 Tamże, s. 336 .

16 „Pomysłowość określeń użytych w tym kontekście jest doprawdy zadziwiająca: zależność naukowa, intelektualny imperializm, amerykański imperializm, socjologiczna kolonizacja, intelektualny kolonializm, dominacja metropolii, teoria metropolii, hegemonia Zachodu, hegemonia Północy, perspektywa Północy zamaskowana jako uniwersalizm, narzucanie koncepcji teorii przez główny nurt socjologii amerykańskiej i europejskiej, ignorowanie Południa, dominacja języka angielskiego, a nawet «otumanienie Zachodem» - prawdziwie innowacyjny dodatek do slangu antyokcydentalizmu”. Tamże, s. 337.

17 M. Burawoy, Ostatni pozytywista, tłum. P. Walczyna, „Studia Litteraria et Historica” 2014/2015, nr 3/4, s. 350-363.

18 Tamże, s. 357. 
logiach narodowych siłę budowania rozwiązań problemów globalnych, które w różnych częściach świata przybierają własną postać, angażują różne grupy interesu, wymagają innych form uzgodnień. W sukurs tym ustaleniom idzie polski socjolog Janusz Mucha, który oblikował swój tekst w omawianym tomie ${ }^{19}$, analizując specyfikę socjologii polskiej jako przypadku socjologii wschodnioeuropejskiej. Powołując się na J. Szczepańskiego, wskazuje, że uniwersalny wymiar socjologii wyrasta z socjologii narodowych. Socjologia zawsze odnosi się do konkretnych problemów społecznych, gospodarczych czy politycznych, ważnych dla danej wspólnoty narodowej, wyrażonych w jej języku i określonych ramami jej kultury ${ }^{20}$.

Ten spór koryfeuszy światowej socjologii o charakterze metateoretycznym stanowi jeden z kontekstów poszukiwań badawczych J. Szymczyka. Dawał on wyraz przekonaniu, że socjologia polska ściśle uwarunkowana była najpierw utratą państwowości w wyniku zaborów, potem dążeniem do odbudowy państwa polskiego, traumą II wojny światowej, oddaniu Polski w sferę wpływu bolszewizmu sowieckiego i jego ideologii, a wreszcie podlegała wszystkim fluktuacjom czasów transformacji ustrojowej po $1989 \mathrm{r}^{21}$ W skazywał na wzloty i upadki polskiej socjologii, ale szczególnie interesowało go zagadnienie, w jakim kierunku będzie zmierzała w przyszłości. Chciał, aby była zdolna do uchwycenia „świata żywego", czyli charakteryzowała się takim podejściem do rzeczywistości społecznej i zachodzących w niej procesów modernizacyjnych, które nie byłoby spojrzeniem „przez pryzmat struktur, bezosobowych mechanizmów, statystyki czy prawdopodobieństwa”, lecz „szukaniem języka opisującego motywy ludzkich działań, które tkwią głęboko w wyznawanych wartościach, $\mathrm{w}$ religii, w historycznym zakorzenieniu"22.

Przewodnikiem w tej drodze uczynił Stanisława Ossowskiego, z pism którego uczył się wiązania obiektywności naukowej z widzeniem ludzkich zachowań, tu i teraz, w konkretnych sytuacjach historycznych. S. Ossowski wywodzi ze szkoły lwowsko-warszawskiej, w której czynności ludzkie traktowane są jako podlegające innemu ujęciu naukowemu niż świat pozaludzki. Osobliwość nauk społecznych jest moim zdaniem pochodną psychologii uprawianej przez Ka-

19 J. Mucha, Socjologia w Europie Środkowo-Wschodniej czy socjologia wschodnioeuropejska, „Przegląd Socjologiczny” 2009, t. 58, nr 2, s. 9-31. Tekst ten jest przeredagowaną polską wersją referatu, wygłoszonego podczas zorganizowanej przez Council for National Associations ISA konferencji „Challenges for Sociology in an Unequal World” w marcu 2009 r. w Tajpej, w sekcji 1: „Facing the hegemony of northern sociologies, and assessing alternatives that have emerged in different parts of the world (including the north itself) in response to that hegemony".

${ }^{20}$ Sto lat socjologii polskiej. Od Supińskiego do Szczepańskiego, red. J. Szacki, Wydawnictwo Naukowe PWN, Warszawa 1995.

${ }^{21}$ J. Szymczyk, Pomiędzy marzeniami a faktami..., s. 10-18.

22 Tamże, s. 18. 
zimierza Twardowskiego ${ }^{23} \mathrm{w}$ powiązaniu z kulturalizmem F. Znienieckiego ${ }^{24}$. „W podejściu twórcy filozoficznej szkoły lwowsko-warszawskiej mamy do czynienia z próbą obiektywnego spojrzenia na czynności jako sytuacje logiczno-semiotyczne zawarte w ludzkich wytworach. Jest to tworzenie perspektywy służącej do określania ludzkich zachowań w różnych sferach życia - od psychicznego po kulturowo-społeczne. Logiczno-semantyczna analiza wytworów jako efektu czynności daje podstawy naukowego ich traktowania, z zaznaczeniem, że zewnętrzne powody zaistnienia danych zjawisk, analitycznie odróżniają się od ukrytych deterministycznych zależności przyczynowo skutkowych właściwych dla zjawisk przyrodniczych. W podejściu autora Chłopa polskiego czynności ludzkie traktowane są jako tworzywo kultury, czyli ładu stosunków pomiędzy wszystkimi uzewnętrznianymi ludzkimi doświadczeniami. W tym ujęciu czynności ludzkie rozumiane antypsychologicznie są odrębną kulturową sferą ludzkiej aktywności określaną przez wartości. Czynności społeczne dziejące się w konkretnych sytuacjach domagają się definiowania przez wykonawców (współczynnik humanistyczny), co staje się podstawą humanistycznego rozumienia, które upodobnia się do przyczyno-skutkowego myślenia o zjawiskach przyrodniczych"25. J. Szymczyk nazywa to zdolnością do uwzględniania w analizach zjawisk społecznych zewnętrznych przejawów świadomości, które z kolei są wiązane z ich rozumieniem przez poszczególne podmioty wydarzeń.

Dla J. Szymczyka podstawowym dziedzictwem polskiej socjologii jest akceptowana $\mathrm{w}$ teorii i praktyce eksploracyjnej perspektywa podmiotowo-przedmiotowa (lub inaczej: psychospołeczna, relacjonistyczna), odrzucająca jednostronne determinanty zjawisk społecznych. Docenia, że unikano zbyt silnego eksponowania różnych dychotomii, co sprawia, że poznawana rzeczywistość nie zostaje „rozszczepiona” na skrajne sfery (np. albo jednostka, albo społeczeństwo). W konsekwencji poza tego typu ujęciem nie pozostają intersubiektywne znaczenia „ucieleśnione” w samej rzeczywistości społecznej i zarazem dla niej konstytutywne. Zdaniem J. Szymczyka istotę zjawisk społecznych można uchwycić tylko wtedy, gdy odrzuci się skrajne podejścia, a zaakceptuje się stanowisko akcentujące, iż między płaszczyzną podmiotową i przedmiotową zachodzi relacja komplementarności. Takie podejście oznacza dowartościowanie kategorii podmiotowości, ale i legitymizację tezy dotyczącej „społecznego tworzenia rzeczywistości”. Zjawiska społeczne „jawią się" po-

${ }^{23}$ K. Twardowski, O czynnościach $i$ wytworach. Kilka uwag z pogranicza psychologii, gramatyki i logiki, Drukarnia Uniwersytetu Jagiellońskiego, Kraków 1911.

${ }^{24}$ F. Znaniecki, Nauki o kulturze. Narodziny i rozwój, tłum. J. Szacki, PWN, Warszawa 1971; tenże, Rzeczywistość kulturowa, tłum. J. Wocial, w: Pisma filozoficzne, t. 2, PWN, Warszawa 1991, s. 459-928.

25 A. Jabłoński, Czynności ludzkie jako obiektywny wymiar badań nauk humanistycznych. Analiza porównawcza koncepcji Kazimierza Twardowskiego i Floriana Znanieckiego, „Roczniki Nauk Społecznych" 2020, t. 12, nr 3, s. 22-23. 
znawczo w świadomości jednostek, dlatego istotnego sensu nabiera w takiej sytuacji koncepcja „współczynnika humanistycznego”. Tego rodzaju perspektywa odnajdywana u najważniejszych polskich socjologów - F. Znanieckiego, F. Mirka, S. Ossowskiego czy J. Turowskiego - może być przyjmowana podczas prowadzenia badań socjologicznych, analizowania wyników owych eksploracji oraz prezentowania różnych obrazów rzeczywistości społecznej.

W tej perspektywie cechą rzeczywistości społecznej jest jej fluktuacyjność, co oznacza, że społeczeństwo jawi się jako nieustanny proces. Dopuszczalne jest więc mówienie o jego różnorakich przeobrażeniach i transformacjach. Jakość owej dynamiki nie sposób poprawnie określić w oderwaniu od podmiotowych potencjalności, ich uwarunkowań oraz aktualnej praktyki (społecznych zdarzeń). Z tej racji wszelkie „regularności” występujące w życiu społecznym są rezultatem internalizacji wartości, norm, reguł gry i wzorów wytworzonych przez ludzi w toku ich interakcji. Historia różnych fenomenów społecznych pokazuje, że właściwe dla nich procesy mają charakter zróżnicowany i niejednoznaczny. Oznacza to, że nie przebiegają one według jakichś abstrakcyjnych praw ekonomii, technologii, polityki itp. ani też nie są dziełem przypadku.

J. Szymczyk jest zdecydowanym zwolennikiem takiej formy socjologii polskiej, która wyróżnia się trwaniem przy obiektywizmie naukowym, ale nie rezygnuje ze specyfiki odnoszenia jej do wydarzeń z życia konkretnych ludzi $\mathrm{w}$ danych sytuacjach historycznych. Chodzi o tworzenie naukowych projektów badawczych, które wolne byłyby od formułowania manifestów ideologicznych, bez względu jakiej są proweniencji. Ale obiektywność naukowa w przypadku nauk społecznych oznacza też otwarcie na kwestie istotne z punktu widzenia danej wspólnoty narodowej. Wspólnym rysem dla polskiej myśli społecznej i socjologicznej była skłonność do traktowania narodu jako tworu suwerennego i pierwotnego wobec państwa, a zarazem jako podstawowej wspólnoty kulturowej w życiu człowieka ${ }^{26}$. Kategoria narodu w niektórych nurtach polskiej socjologii awansowała do rangi podstawowej kategorii heurystycznej, zastępując ogólne pojęcie społeczeństwa. Nie służyła ona jednak tylko do opisu rzeczywistości społecznej, ale była też „swoistym imperatywem moralnym”27.

26 „Polska była narodem bez własnego państwa, a także bez terytorialnie i politycznie zjednoczonego społeczeństwa. Ze względu na to, najważniejszym zadaniem dla polskich polityków, przywódców społecznych, pisarzy i innych artystów, a także badaczy społecznych, było przyczynianie się do odzyskania suwerenności politycznej i kulturowej. Suwerenność i wolność (nie liberalna wolność indywidualna, lecz zbiorowa wolność narodu, jego niezależność od innych, zewnętrznych bytów politycznych) była najwyżej cenioną wartością społeczną, a nawet moralną. "Problemy społeczne», na przykład klasowe, w tym emancypacja uboższych klas czy warstw społecznych, walka klas, społeczna rewolucja przeciw systemowi burżuazyjnemu, miały znaczenie wtórne". J. Mucha, Socjologia w Europie Środkowo-Wschodniej..., s. 19.

27 J. Szymczyk, Pomiędzy marzeniami a faktami..., s. 21. 
Analiza tekstów polskich socjologów pozwoliła J. Szymczykowi ukazać, w jaki sposób unikali oni stanowisk redukcjonistycznych w sprawie np. statusu świadomości społecznej, ontologii społecznej czy internalizacji określonych kategorii aksjologicznych. O specyfice rozumienia przez nich zjawisk społecznych stanowi „zakorzenienie” treści tych fenomenów w świadomości poszczególnych osób, w interakcjach międzyludzkich oraz intersubiektywnych przekonaniach jednostek. Należy jednak wyraźnie podkreślić, że akcentowanie perspektywy psychospołecznej czy uwzględnianie różnych czynników kompozycji określonych zjawisk, obiektów, procesów nie oznacza kwestionowania realnej i metodologicznej „suwerenności” owych bytów. Funkcjonują one bowiem w pewnej symbiozie, choć zarazem istnieją między nimi różnice. Nie można ich utożsamiać ze sobą i redukować do siebie nawzajem. W relacji między indywidualizmem a holizmem, sferą prywatną a publiczną itp. można dostrzec pewną wspólną płaszczyznę zjawisk, zachowań, w których realizowane są jednocześnie specyficzne i osobliwe funkcje oraz założenia i cele poszczególnych kategorii. W konsekwencji zakres tych pojęć można przedstawić raczej w formie zbiorów wzajemnie na siebie zachodzących niż całkowicie się pokrywających.

\section{Aksjologia w socjologii polskiej}

Auguste Comte chciał uczynić z socjologii naukę wolną od wartościowania, co oznaczało zastąpienie wartościowania teologiczno-moralnego (dobre, święte/ złe, grzeszne), metafizycznego (prawda/fałsz) przez pozytywne, czyli naukowe (zweryfikowane empirycznie/niezweryfikowane). W przypadku zachowań społecznych człowieka, które są przedmiotem badań socjologicznych, oznaczać to mogło bardzo wiele - ruchy fizyczne, odruchy biologiczne, doznania zmysłowe - ale ostatecznie pozbawiało widzenia duchowego.

J. Szymczykowi nie chodziło o traktowanie życia duchowego ludzi jako przedmiotu modnej obecnie refleksji socjologicznej, często traktowanej jako alternatywa wobec życia religijnego, ale o najważniejszą sferę ludzkiej aktywności wyrażającą się w kulturze, twórczości artystycznej, w odniesieniach do transcendencji. Tak pojmowana była zarówno w ujęciu Henriego de Saint-Simona, jak A. Comte’a, którzy proklamowali „religię ludzkości”, czyli de facto sekularyzm. Odwołanie do duchowości to próba uznania religijnego wymiaru życia człowieka jako poddanego władzy rozumu pozytywnego. „Inaczej niż w post-comteowskiej socjologii zachodnioeuropejskiej, również myślenie w kategoriach religijnych było bardzo popularne w naukach społecznych i humanistyce w Polsce i w innych krajach środkowo i wschodnioeuropejskich. Z jednej strony powinniśmy więc włączyć do naszej analizy społeczne nauczanie Kościoła rzymskokatolickiego, które zawsze powiązane było z socjologią (...). Z drugiej strony warto 
podkreślić to, że w kręgach intelektualnych, a nawet akademickich, popularne było myślenie w kategoriach mistycznych, a mesjanizm narodowy był bardzo żywy"28. Nawet uniwersalne problemy podejmowane w pracach XIX-wiecznych klasyków socjologii były interpretowane w zależności od możliwości ich zastosowania w polskich warunkach.

Socjologię S. Ossowskiego określił J. Szymczyk jako zaangażowaną w wartości. Takie zaangażowanie, przypisywane autorowi Osobliwości nauk społecznych, rozumiane jest w ten sposób, że „nauka (socjologia) jest aksjologicznie zaangażowana (niezależnie od deklaracji badacza), bo musi jakoś brać pod uwagę sferę wartości”"29. Branie pod uwagę wartości w nauce nie oznacza zatem „wartościowania w nauce”, ale uznanie nauki za wartość, co przekłada się na „postawę badacza, która łączy w sobie poszukiwanie prawdy z dążeniem do doskonalenia samego siebie, jako człowieka oraz środowiska społecznego, w którym żyje” ${ }^{\prime 30}$. Takie podejście socjologa do badanej rzeczywistości to aspiracja do osiągnięcia rzetelnego opisu naukowego jako jednego ze szczególnych wyzwań, przed którym może stanąć człowiek. Jest to nawiązanie do Platońskiego ideału mędrca, który cnotę mądrości traktuje jako zobowiązanie do wyjścia z jaskini złudzeń i wyciagnięcia z niej ludzi tkwiących w świecie iluzji. Nie ma to jednak wiele wspólnego z budowaniem ideologiczno-politycznego programu kierowania społeczeństwem-państwem. J. Szymczyk uznaje przestrogę S. Ossowskiego, aby socjolog nie został sprowadzony do funkcji lektora partyjnego, propagandysty lub apologety określonego porządku politycznego ${ }^{31}$. Wzmacnia to, podkreślając stanowisko F. Mirka wobec socjologii, która nie powinna się opierać na z góry założonym światopoglądzie, a tym bardziej narzucać innym jakąś ideologię.

W tym miejscu warto podkreślić pewną odmienność podejść, jakie zaprezentowaliśmy we wspomnianej już wspólnej książce. Chodziło o rozumienie zasadności używania wyrażenia „socjologia katolicka/chrześcijańska”32. Jeżeli ja uważałem, że jest ona wyrazem polskiej sytuacji realnego zagrożenia bolszewizmem, któremu należało przeciwstawić wyraźnie określoną ideowo alternatywę, to J. Szymczyk podkreślał m.in. za F. Mirkiem, że socjolog powinien pozostać wierny jedynie wymogom prawdy, zatem należy zrezygnować zarówno z przymiotników chrześcijańska/katolicka, jak i marksistowska. Wspólnie uznaliśmy jednak, że socjologia katolicka i socjologia bezprzymiotnikowa zbliżają się do

${ }^{28}$ J. Mucha, Socjologia w Europie Środkowo-Wschodniej..., s. 19.

${ }^{29}$ J. Szymczyk, W świecie ludzkich kreacji. Stanisława Ossowskiego koncepcja rzeczywistości społecznej, Wydawnictwo KUL, Lubin 2005, s. 436.

30 Tamże, s. 436.

${ }^{31}$ S. Ossowski, Nauki humanistyczne a ideologia społeczna, w: Dzieła, t. 4. O nauce, PWN, Warszawa 1967, s. 103.

32 A. Jabłoński, J. Szymczyk, Realist-axiological Perspectives and Images of Social Life..., s. 16-17, 33. 
siebie, gdy łączy ich rozumienie zjawisk społecznych jako powiązanych z ludzkimi czynnościami, które mogą być poddawane ocenie normatywnej.

Jest to wpisane w polską tradycję uprawiania socjologii, która u swoich początków nie wykluczała stosowania pojęć normatywnych, co służyło kształtowaniu postaw moralnych Polaków i ich samoświadomości ${ }^{33}$. Dlatego dla J. Szymczyka wartości ${ }^{34}$ jako istotny element tworzący grupy społeczne są specyficzne dla poszczególnych kultur i społeczeństw: „Stanowią one o istocie i specyfice kultury, mentalności i świadomości jednostek, grup społecznych. Przez jednych badaczy są one nazywane wartościami podstawowymi, naczelnymi lub centralnymi, przez innych - dominującymi lub z rdzennymi. Bez akceptacji tego typu wartości żadne społeczeństwo, a przeto także i państwo, nie może istnieć czy sprawnie funkcjonować" ${ }^{35}$. Jest to ważne w czasie wychodzenia Polski z komunistycznego, a potem postkomunistycznego porządku społeczno-gospodarczego oraz poddania się wpływowi różnych idei i wartości nabierających w nowych warunkach szczególnego znaczenia, często sprzecznego z oczekiwanym ${ }^{36}$. Jak zauważa J. Szymczyk: „Niewątpliwie występujące w naszym kraju skutki czy oddziaływania procesów transformacji systemowej, globalizacji, integracji europejskiej, relatywizacji społecznych grup odniesienia, detradycjonalizacji, homogenizacji lub hybrydyzacji społeczno-kulturowej, szeroko pojętego pluralizmu, rozwoju nowych mediów - mają wpływ na internalizację wartości i kształtowanie więzi społecznych, tożsamości przez Polaków"37

Dlatego w przypadku zadań, jakie stoją przed socjologią, przekłada się to na zdolność do rozpoznania jej zadań i celów oraz uniknięcia błędu naturalizmu ${ }^{38}$. Socjologia powinna być empiryczną odpowiedzią na pytania ważne z punktu widzenia jednostki ludzkiej partycypującej w życiu społecznym. Wiąże się to z jej postulatywnym i projektującym charakterem, który J. Szymczyk odnajduje w pismach S. Ossowskiego zawierających propozycje reform społecz-

${ }^{33}$ K.Z. Sowa, O jednym z możliwych sposobów interpretacji dziejów socjologii polskiej, „Studia Socjologiczne" 1983, nr 4, s. 147-160.

34 „Wartości nie są bowiem gotowymi instrumentami, których można w bezpośredni i racjonalny sposób użyć do osiągnięcia zamierzonych celów. One otwierają i ukierunkowują na pewien «horyzont możliwości», który może, ale nie musi, być wykorzystany przez aktorów. Nie ma prostych zależności między deklarowanym poparciem dla jakichś działań zbiorowych - z perspektywy określonych wartości - a wzięciem w nich faktycznego udziału”. J. Szymczyk, Zamiast wprowadzenia..., s. 6.

35 Tenże, Wartości a zachowanie i działania społeczne, w: Segmenty aktywności społecznej a wartości. Idee i praktyka, Wydawnictwo KUL, Lublin 2012, s. 15.

${ }^{36}$ Zob. Z. Krasnodębski, Demokracja peryferii, Słowo/Obraz Terytoria, Gdańsk 2003; R. Matyja, Wyjście awaryjne. O zmianie wyobraźni politycznej, Karakter, Kraków 2018.

${ }^{37}$ J. Szymczyk, Wartości a zachowania i działania społeczne..., s. 35.

${ }^{38}$ Chodzi głównie o naturalizm przedmiotowy, który oznacza redukcję przedmiotu nauk społecznych do faktów naturalnych - fizycznych (fizykalizm, mechanicyzm) i biologicznych (organicyzm, ewolucjonizm). Zob. A. Jabłoński, Naturalizm, w: Encyklopedia katolicka, t. 13, red. E. Gigilewicz, TN KUL, Lublin 2009, kol. 808-811. 
nych w ramach konkretnych rozwiązań instytucjonalnych i organizacyjnych. Pozytywnie odnosi się też do przeprowadzonej przez autora O osobliwościach nauk społecznych krytyki wykorzystywania osiągnięć socjologii przez władze w różnych celach socjotechnicznych: „Z tego m.in. powodu miał on krytyczny stosunek do amerykańskiej socjologii empirycznej, inspirowanej filozofią neopozytywistyczną, za jej "wąskodiagnostyczne», "empirycystyczne» nastawienie do badanych zjawisk" ${ }^{39}$. J. Szymczyk uznaje to nie tylko za efekt humanistycznej orientacji polskiego socjologii, lecz także za efekt widzenia kwestii społecznych w jej kontekście historyczno-kulturowym. Interpretacja faktów społecznych jako humanistycznych za F. Znanieckim wymaga uwzględnienia sposobów ich rozumienia przez uczestników danego wydarzenia społecznego.

J. Szymczyk świadomy, że podejście do kwestii ludzkich czynności stanowi konieczną perspektywę refleksji naukowej, jest w polskiej socjologii propagatorem modelu badawczego orientacji wartościujących. Stworzył na użytek badań własnych i prac powstających pod jego kierunkiem model badawczy, który zatytułował Orientacje wartościujące a wzory aktywności społecznej. "Zawiera on w sobie takie segmenty, elementy składowe, jak m.in.: rudymentarne rozumienie wartości ( $w$ tym także komponentów postaw - afektywnego i kognitywnego), ogląd rzeczywistości społecznej z perspektywy orientacji indywidualistycznej i republikańsko-konserwatywnej, w które "wplecione» są typy statusu (przypisanego, osiąganego), kategorie wolności i równości, opcja materialistyczna i postmaterialistyczna, elementy kapitału społecznego (spajający i pomostowy), rodzaje zaufania (zagęszczone i rozproszone), behawioralny komponent postaw oraz typologia orientacji życiowych. Model tan nadaje się do aplikacji podczas przeprowadzenia raczej badań jakościowych przy wykorzystaniu choćby kwestionariusza pogłębionego" ${ }^{40}$. Jest to model badawczy, będący powiązaniem dorobku współczesnych polskich socjologów, m.in. takich jak: J. Koralewicz i M. Ziółkowski, S. Marczuk, P. Sztompka, P. Ruszkowski, K. Wielecki, T. Szawiel, A. Matuchniak-Krasuska czy E. Zimnica-Kuzioła ${ }^{41}$. Wypracowane przez nich analizy różnych odniesień człowieka do otoczenia,

${ }^{39}$ J. Szymczyk, $W$ świecie ludzkich kreacji..., s. 437.

${ }^{40}$ Tenże, Wartości a zachowania i działania społeczne..., s. 25-26.

${ }^{41}$ J. Koralewicz, M. Ziółkowski, Mentalność Polaków. Sposoby myślenia o polityce, gospodarce i życiu społecznym 1988-2000, Wydawnictwo Naukowe Scholar, Warszawa 2003; S. Marczuk, Orientacje wartościujące nauczycieli w III Rzeczypospolitej. Studium z socjologii edukacji, Wydawnictwo Wyższej Szkoły Pedagogicznej, Rzeszów 2001; P. Sztompka, Socjologia zmian społecznych, tłum. J. Konieczny, Znak, Kraków 2005; P. Ruszkowski, Segmentacja społeczeństwa polskiego - model teoretyczny, „Uniwersyteckie Czasopismo Socjologiczne" 2011, nr 6, s. 4-22; K. Wielecki, Podmiotowość w dobie kryzysu postindustrializmu. Między indywidualizmem a kolektywizmem, Centrum Europejskie UW, Warszawa 2003; T. Szawiel, Kody kulturowo-mentalne po 1989 roku - czynniki i kierunki zmian, w: Modernizacja Polski. Kody kulturowe a mity, red. J. Szomburg, Instytut Badań nad Gospodarką Rynkową, Gdańsk 2008, s. 103-108; A. Matuchniak-Krasuska, Gust i kompetencja. Społeczne zróżnicowanie recepcji ma- 
obejmujące różne komponenty i segmenty, zostały wykorzystane jako strukturalne elementy proponowanego modelu badawczego. Ma to określać miejsce, status, aktywność i stosunek do różnych obiektów badanych jednostek, a także ich dążenia „do osiągnięcia i internalizacji wartości jako celów życiowych oraz różne mechanizmy i metody mające wpływ na kształtowanie ich osobowości"42. Tak konstruowane orientacje wartościujące porządkowane są przez J. Szymczyka w opozycyjne pary typów idealnych, określających wymiary lub kontynuacje norm i standardów działania uczestników interakcji. Jedną z nich jest opozycja, którą do nauk społecznych wprowadził R. Inglehart, orientacji materialistycznej, charakteryzującej wartości ekonomiczno-socjalne do postmaterialistycznej, charakteryzującej wartości kulturowe.

Podziałowi temu poświęcił J. Szymczyk swój ostatni tekst publicystyczny Bieda pozamaterialna ${ }^{43}$. W ramach orientacji wartościujących odróżnił ubóstwo ducha od ubóstwa w duchu. Pierwszy rodzaj ubóstwa opiera się na postawie „mieć”, postawieniu na wartości materialne, gromadzeniu dóbr doczesnych, stawania się niewolnikiem naszych hedonistycznych i utylitarnych pragnień. Drugi rodzaj ubóstwa priorytetem czyni postawę „być”, wartości pozamaterialne, czyli pokorne uznawanie własnych ograniczeń i nietrwałości wszystkiego, co doczesne. Ubóstwo ducha to ubóstwo pozamaterialne, bieda moralna, lenistwo duchowe, acedia (choroba duszy), ubóstwo kultury osobistej (zwłaszcza języka). W sferze publicznej przejawia się także jako poprawność polityczna, przybierająca formę narzucenia jednej interpretacji wydarzeń. „Przy pomocy aberracyjnej poprawności politycznej przemilcza lub przeinacza się pewne niewygodne fakty, obrzydza lub ośmiesza się np. narodową tradycję i historię, pogardza się martyrologią Polaków, zubaża się dorobek ojczystej i klasycznej literatury" ${ }^{44}$. Największym zagrożeniem ubóstwa ducha jest ograniczenie własnych aspiracji do doczesności i zapomnienie, „że przez bramę śmierci człowiek przenosi to, kim jest, a nie to, co posiada" 4 .

\section{Podsumowanie}

J. Szymczyk osadził swoją twórczość w tradycji socjologii polskiej. Nawiązywał do najważniejszych osiągnięć zarówno szkoły, z której się wywodził, jak i współczesnych klasyków podejścia humanistycznego. W polskiej tradycji

larstwa, Wydawnictwo Uniwersytetu Łódzkiego, Łódź 1988; E. Zimnica-Kuzioła, Światła na widownię. Socjologiczne studium publiczności teatralnej, Wydawnictwo Uniwersytetu Łódzkiego, Łódź 2003.

42 J. Szymczyk, Wartości a zachowania i działania społeczne..., s. 26-27.

${ }^{43}$ Tenże, Bieda pozamaterialna, „Wiara, Patriotyzm i Sztuka (WPiS)”, 2020, nr 7-8, s. 25-28.

${ }^{44}$ Tamże, s. 28.

45 Tamże. 
socjologicznej odkrywał „złoty środek” pomiędzy naukowym uniwersalizmem a socjologią narodową, pomiędzy widzeniem struktur społecznych a uwzględnieniem podmiotowej aktywności jednostek. Czynił to, osadzając swoje ustalenia naukowe $\mathrm{w}$ ramach personalistycznego widzenia człowieka. Zastosował to szczególnie do uchwycenia sposobów socjologicznego odnoszenia się do wartości. Potwierdziła się zatem teza, że w tekstach J. Szymczyka polska socjologia postrzegana jest jako powiązana $\mathrm{z}$ określonym systemem wartości, co wyznacza sposób identyfikowania w niej realnych problemów i poszukiwania najlepszych ich rozwiązań. Opracowanie przez niego modelu badawczego orientacji aksjologicznych jest wyrazem zabiegu pogłębiania tradycji polskiego myślenia socjologicznego i osadzania jej w odniesieniu do historycznych warunków życia wspólnoty polskiej.

\section{Bibliografia}

Burawoy M., Ostatni pozytywista, tłum. P. Walczyna, "Studia Litteraria et Historica” 2014/2015, nr 3/4, s. 350-363.

Facing an Unequal World. Challenges for a Global Sociology, red. M. Burawoy, M. Chang, M. Fei-yu Hsieh, Institute of Sociology at Academia Sinica, Council of National Associations of International Sociological Association, Academia Sinica, Taipei 2010.

Jabłoński A., Budowanie społeczeństwa wiedzy. Zarys teorii społecznej Karla. R. Poppera, Wydawnictwo KUL, Lublin 2006.

Jabłoński A., Czynności ludzkie jako obiektywny wymiar badań nauk humanistycznych. Analiza porównawcza koncepcji Kazimierza Twardowskiego i Floriana Znanieckiego, „Roczniki Nauk Społecznych" 2020, t. 12, nr 3, s. 22-23.

Jabłoński A., Filozoficzna interpretacja życia społecznego w ujęciu Petera Wincha, Redakcja Wydawnictw KUL, Lublin 1998.

Jabłoński A., Naturalizm, w: Encyklopedia katolicka, t. 13, red. E. Gigilewicz, TN KUL, Lublin 2009, kol. 808-811.

Jabłoński A., Szymczyk J., Realist-axiological Perspectives and Images of Social Life. A Century of Sociology at John Paul the Second Catholic University of Lublin, Peter Lang, Berlin 2020.

Koralewicz J., Ziółkowski M., Mentalność Polaków. Sposoby myślenia o polityce, gospodarce i życiu społecznym 1988-2000, Wydawnictwo Naukowe Scholar, Warszawa 2003.

Kowalczyk S., Ciało człowieka w refleksji filozoficznej, Wydawnictwo KUL, Lublin 2009.

Kowalczyk S., Człowiek a społeczność. Zarys filozofii społecznej, Redakcja Wydawnictw KUL, Lublin 1996.

Kowalczyk S., Człowiek w myśli współczesnej. Filozofia współczesna o człowieku, Wydawnictwo „Michalineum", Warszawa 1990.

Kowalczyk S., Elementy filozofii i teologii sportu, TN KUL, Lublin 2002.

Kowalczyk S., Filozofia kultury. Próba personalistycznego ujęcia problematyki, Redakcja Wydawnictw KUL, Lublin 1996.

Kowalczyk S., Filozofia wolności. Rys historyczny, Redakcja Wydawnictw KUL, Lublin 1999.

Kowalczyk S., Idea sprawiedliwości społecznej a myśl chrześcijańska, Redakcja Wydawnictw KUL, Lublin 1998.

Kowalczyk S., Wolność natura i prawem człowieka. Indywidualny i społeczny wymiar wolności, Wydawnictwo Diecezjalne, Sandomierz 2000.

Kowalczyk S., Współczesny kryzys ideowo-aksjologiczny, Wydawnictwo KUL, Lublin 2011. 
Krasnodębski Z., Demokracja peryferii, Słowo/Obraz Terytoria, Gdańsk 2003.

Marczuk S., Orientacje wartościujqce nauczycieli w III Rzeczypospolitej. Studium z socjologii edukacji, Wydawnictwo Wyższej Szkoły Pedagogicznej, Rzeszów 2001.

Matuchniak-Krasuska A., Gust i kompetencja. Społeczne zróżnicowanie recepcji malarstwa, Wydawnictwo Uniwersytetu Łódzkiego, Łódź 1988.

Matyja R., Wyjście awaryjne. O zmianie wyobraźni politycznej, Karakter, Kraków 2018.

Mucha J., Socjologia w Europie Środkowo-Wschodniej czy socjologia wschodnioeuropejska, „Przegląd Socjologiczny" 2009, t. 58, nr 2, s. 9-31.

Ossowski S., Nauki humanistyczne a ideologia społeczna, w: Dzieła, t. 4. O nauce, PWN, Warszawa 1967.

Ruszkowski P., Segmentacja społeczeństwa polskiego - model teoretyczny , Uniwersyteckie Czasopismo Socjologiczne" 2011, nr 6, s. 4-22.

Sowa K.Z., O jednym z możliwych sposobów interpretacji dziejów socjologii polskiej, „Studia Socjologiczne" 1983, nr 4, s. 147-160.

Sprawstwo. Teorie, metody, badania empiryczne w naukach społecznych, red. A. Mrozowicki, O. Nowaczyk, I. Szlachcicowa, Zakład Wydawniczy „Nomos", Kraków 2013.

Sto lat socjologii polskiej. Od Supińskiego do Szczepańskiego, red. J. Szacki, Wydawnictwo Naukowe PWN, Warszawa 1995.

Szawiel T., Kody kulturowo-mentalne po 1989 roku - czynniki i kierunki zmian, w: Modernizacja Polski. Kody kulturowe a mity, red. J. Szomburg, Instytut Badań nad Gospodarką Rynkową, Gdańsk 2008, s. 103-108.

Sztompka P., Kolejna socjologiczna utopia, tłum. P. Walczyna, ,'Studia Litteraria et Historica" 2014/2015, nr 3/4, s. 335-349.

Sztompka P., Socjologia zmian społecznych, tłum. J. Konieczny, Znak, Kraków 2005.

Szymczyk J., Bieda pozamaterialna, „Wiara, Patriotyzm i Sztuka (WPiS)”, 2020, nr 7-8, s. 25-28.

Szymczyk J., Elements of the Application of the Complementarity Principle. Issues of the Sociology of Subjectivity and Social Structures, Wydawnictwo Adam Marszałek, Toruń 2014.

Szymczyk J., Odkrywanie wartości. Z problematyki socjologiczno-aksjologicznej, Polihymnia, Lublin 2004.

Szymczyk J., Pomiędzy marzeniami a faktami. Szkice socjologiczne, Norbertinum, Lublin 2005.

Szymczyk J., Wartości a zachowania i działania społeczne, w: Segmenty aktywności społecznej a wartości. Idee i praktyka, red. J. Szymczyk, Wydawnictwo KUL, Lublin 2012, s. 9-35.

Szymczyk J., W świecie ludzkich kreacji. Stanisława Ossowskiego koncepcja rzeczywistości społecznej, Wydawnictwo KUL, Lubin 2005.

Szymczyk J., Zamiast wprowadzenia. O Katedrze Socjologii Makrostruktur i Ruchów Społecznych, w: Wartości, interesy, struktury społeczne. Uwarunkowania ludzkiej kreatywności i partycypacji w życiu publicznym, Studia nad Wartościami. Perspektywa Socjologii Makrostruktur i Ruchów Społecznych, t. 1, red. J. Szymczyk, Norbertinum, Lublin 2010, s. 5-15.

Twardowski K., O czynnościach i wytworach. Kilka uwag z pogranicza psychologii, gramatyki i logiki, Drukarnia Uniwersytetu Jagiellońskiego, Kraków 1911.

Wielecki K., Podmiotowość w dobie kryzysu postindustrializmu. Między indywidualizmem a kolektywizmem, Centrum Europejskie UW, Warszawa 2003.

Zimnica-Kuzioła E., Światła na widownię. Socjologiczne studium publiczności teatralnej, Wydawnictwo Uniwersytetu Łódzkiego, Łódź 2003.

Znaniecki F., Nauki o kulturze. Narodziny i rozwój, tłum. J. Szacki, PWN, Warszawa 1971.

Znaniecki F., Rzeczywistość kulturowa, tłum. J. Wocial, w: Pisma filozoficzne, t. 2, PWN, Warszawa 1991, s. 459-928. 


\section{Streszczenie}

Artykuł dotyczy kwestii rozumienia przez Jana Szymczyka polskiej socjologii jako osadzonej w uniwersalnych wartościach humanistycznych. Celem jego jest ukazanie wkładu Szymczyka w rozumienie dziedzictwa rodzimej socjologii w zakresie jako powiązanej z określonym systemem wartości, co wyznacza sposób identyfikowania w niej realnych problemów i poszukiwania najlepszych ich rozwiązań. Odnoszenie się do socjologii polskiej ma w pismach Szymczyka charakter świadomego zabiegu pogłębiania tradycji myślenia socjologicznego i osadzania jej w historycznych warunkach życia określonej wspólnoty. Lubelski socjolog nie czynił jednak tego w przekonaniu, że o porządku społecznym powinno się mówić w ramach socjologii narodowych, ale uznawał, że uniwersalny język naukowy wymaga osadzenia w systemie wartości właściwych dla danej wspólnoty narodowej.

Słowa kluczowe: wartości, orientacje wartościujące, socjologia polska, aksjologia, personalizm

\section{Jan Szymczyk's Understanding of the Axiological Dimension of Polish Sociology}

\section{Summary}

The article concerns the issue of Jan Szymczyk's understanding of Polish sociology as rooted in universal humanistic values. The aim of the article is to show Szymczyk's contribution to understanding the heritage of Polish sociology as related to a specific system of values, which determines the way of identifying real sociological problems and searching for the best solutions to them. In Szymczyk's writings, reference to Polish sociology takes the form of a deliberate procedure of deepening the tradition of sociological thinking and embedding it in the historical conditions of life of a specific community. Nonetheless, the Lublin sociologist did not believe that social order should be discussed within the framework of national sociologies, but claimed that a universal scientific language requires embedding in the system of values appropriate for a given national community.

Key words: values, value orientations, Polish sociology, axiology, personalism 